\title{
Vertical distribution of photosynthetic sulphur bacteria linked to saline gradients in Lake 'El Tobar' (Cuenca, Spain)
}

\author{
L. J. Garcia-Gil ${ }^{1, *}$, E. Vicente ${ }^{2}$, A. Camacho ${ }^{2}$, C. M. Borrego ${ }^{1}$, X. Vila ${ }^{1}$, X. P. Cristina ${ }^{1}$, \\ J. Rodriguez-Gonzalez ${ }^{1}$ \\ ${ }^{1}$ Institute of Aquatic Ecology, University of Girona, Campus de Montilivi, 17071 Girona, Spain
${ }^{2}$ Dept of Microbiology and Ecology, Faculty of Sciences, University of Valencia, Burjassot, 46100 Valencia, Spain
}

ABSTRACT: The meromictic lake 'El Tobar' was sampled at 3 time points during the annual cycle, coinciding with the thermal stratification period. The photosynthetic microbial community was composed of mixolimnetic oxygenic phototrophs, which were distributed through the mixolimnion, phycoerytrine-containing unicellular cyanobacteria and sulphur phototrophic bacteria placed at the halocline. During the stratification period anoxic conditions, formerly confined to the monimolimnion, moved $1 \mathrm{~m}$ upwards, reaching freshwater positions. Consequently, photosynthetic bacteria were re-arranged into

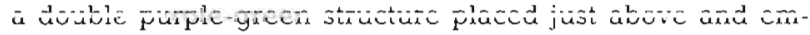
bedded in the chemocline. In the freshwater layers we found a population of the purple sulphur bacterium Chromatium minus placed just above a population of the brown-colored green sulphur bacterium Chlorobium phaeobacteroides. A few centimeters below we found Lamprocystis modestohalophilus overlying Chlorobium vibrioforme. This peculiar structure was probably due to anoxic conditions reaching upper positions at the end of the stratification period, thus allowing the growth of freshwater phototrophic bacteria. The distribution of the phototrophic bacterial populations reveals a vertical structure which is strongly influenced by salinity, whereas light intensity only determines the relative position of purple and green bacteria.

KEY WORDS: Meromictic lake - Phototrophic sulphur bacteria - Halocline Population dynamics - Chromatium - Chlorobium

Accumulation of phototrophic bacterial biomass in the oxic-anoxic boundary of sulphide-containing lakes and waterbodies occurs frequently if sufficient light is available (Pfennig 1989). An extensive revision of photosynthetic bacteria-containing waterbodies can be found in van Gemerden \& Mas (1995). Meromictic lakes are often considered as stable aquatic ecosystems in which seasonality does not affect the microbial community as much as in holomictic lakes. The latter

•E-mail: garciagil@morgat.udg.es are subjected to an annual regime of mixing and stratification that provides a high degree of variability in the physical and chemical parameters, depending on the season. However, in some meromictic lakes redoxclines are placed at such a depth that light is the limiting factor for bacterial growth during most of the year.

In Lake 'El Tobar' the vertical structure of both the water column and the bacterial community is strongly influenced hy the nrecenre of a charn calinity gradient A complete physical and chemical characterization of the lake as well as a preliminary biological study can be found in Vicente et al. (1993) and Miracle et al. (1993). Here we study the seasonal dynamics of the photosynthetic bacterial populations in this lake, which have not been studied to date. This lake has hypersaline waters in the monimolimnion and lowmineralised freshwater in the upper $12 \mathrm{~m}$. Thus it was of interest to identify the dominant physiological (freshwater or saline) group of phototrophic sulphur bacteria in the gradients established. The field work was scheduled to cover a whole stratification period. Sampling was carried out to cover the onset of thermal stratification (spring), complete stagnation (summer) and final steps of the stratification (early fall).

Materials and methods. Study area: Lake 'El Tobar' is a solution lake located $1250 \mathrm{~m}$ above sea level in the karstic region of Cuenca (Spain). It is composed of 2 basins. Field work was done in the smallest and deepest one, which is an elongated circular shaped meromictic basin, found on the northern side of the lake, and contains a permanently anoxic saline monimolimnion starting at ca 12 m depth (Vicente et al. 1993).

Field measurements: Water temperature, conductivity, $\mathrm{pH}$, redox potential and dissolved oxygen concentration were simultaneously measured in situ with a Hydrolab DS3 multiprobe system. 
Light measurements were performed around noon with a battery-powered underwater spectroradiometer (LI-1800 UW; Li-Cor, Inc.) operated with a portable LCD terminal. Downwelling irradiance spectra between 300 and $850 \mathrm{~nm}$, at $2 \mathrm{~nm}$ intervals, were obtained from the surface to the depth with the minimum light detectable for the spectroradiometer $\left(5 \times 10^{-4} \mu \mathrm{E} \mathrm{m} \mathrm{m}^{-2} \mathrm{~s}^{-1} \mathrm{~nm}^{-1}\right)$. The irradiance values at each depth were integrated from 400 to $700 \mathrm{~nm}$ to obtain the PAR (photosynthetically available radiation).

Samples were taken from roughly the center of the basin, just over the deepest point, using a special sampling device, similar to the one described earlier by Jørgensen et al. (1979), consisting of 2 base-opposed cones which are connected to an impellent pump powered by a $12 \mathrm{~V}$ car battery. This gives a sampling flow of $21 \mathrm{~min}^{-1}$ and is specially designed both to avoid disruption of the multilayered gradients and to minimize turbulence. Water was collected in screw-capped bottles of various capacities and preserved from direct sunlight in a portable icebox. Samples were processed for chemical and pigment analysis either at the moment of sampling or shortly after.

Cell counts: The numbers of phototrophic sulphur bacteria were determined after passage of samples through $0.2 \mu \mathrm{m}$ pore diameter cellulose acetate filters and subsequent treatment with erythrosine (Jones 1979). The number of cells of each species was counted on dried filters at $1250 \times$ in a Zeiss phase contrast microscope. Phototrophic bacteria were identified by using morphological and metabolic criteria according to Bergey's manual of systematic bacteriology (Staley et al. 1989).

Pigment analysis: Known volumes $(0.3$ to 1 l) of water samples were passed through $0.45 \mu \mathrm{m}$ pore diameter Supor ${ }^{\otimes}$ filters (Gelman Sciences) covered with a thin layer of $\mathrm{MgCO}_{3}$, as described by Guerrero et al. (1985). The cell material retained in the filter was re-suspended in $5 \mathrm{ml}$ of $100 \%$ acetone and stored at $-30^{\circ} \mathrm{C}$ for 24 h to ensure the complete extraction of pigments. HPLC analyses of pigment extracts were performed as described by Borrego \& Garcia-Gil (1994). Quantitative pigment analyses were performed with calibration curves prepared according to the extinction. coefficients for each bacteriochlorophyll (Bchl) (Takahashi \& Ichimura 1968, Oelze 1985). Bchl e concentration was calculated according to Borrego et al. (1999).

Results and discussion. The vertical distribution of physical and chemical variables, and bacterial populations was strongly influenced by the presence of an extremely sharp picnocline, which was invariably placed at $13.25 \mathrm{~m}$. Conductivity values below this boundary were higher than $100 \mathrm{mS} \mathrm{cm}^{-1}$, indicating high $\mathrm{NaCl}$ concentrations (Vicente et al. 1993). Below this chemocline oxygen was absent.

Three layers of distinct optical properties were observed in the water column (Fig. 1). The first, from the surface to about $10 \mathrm{~m}$, was the aerobic layer, whose main absorbing particles were phytoplankton. The light extinction coefficient $(\eta)$ for this layer was fairly constant $\left(0.16\right.$ to $\left.0.18 \mathrm{~m}^{-1}\right)$ during the sampling period. The second layer corresponded to the span of the photosynthetic bacterial community. In this layer, $\eta$ was more sensitive to the density of these populations. A maximum coefficient of $0.48 \mathrm{~m}^{-1}$ was measured in July. Finally, just below the picnocline, where no living bacteria were detected, a stronger light extinction was measured, with $\eta$ up to $1.74 \mathrm{~m}^{-1}$. This high optical den sity may be due to cell debris and other particulate organic matter, which accumulates at this level due to the sudden increase in water density. PAR reaching the phototrophic bacterial layer ranged between 2 and $10 \mu \mathrm{E} \mathrm{m}^{-2} \mathrm{~s}^{-1}$. These values represent a fairly constant $0.3 \%$ of surface incident light.

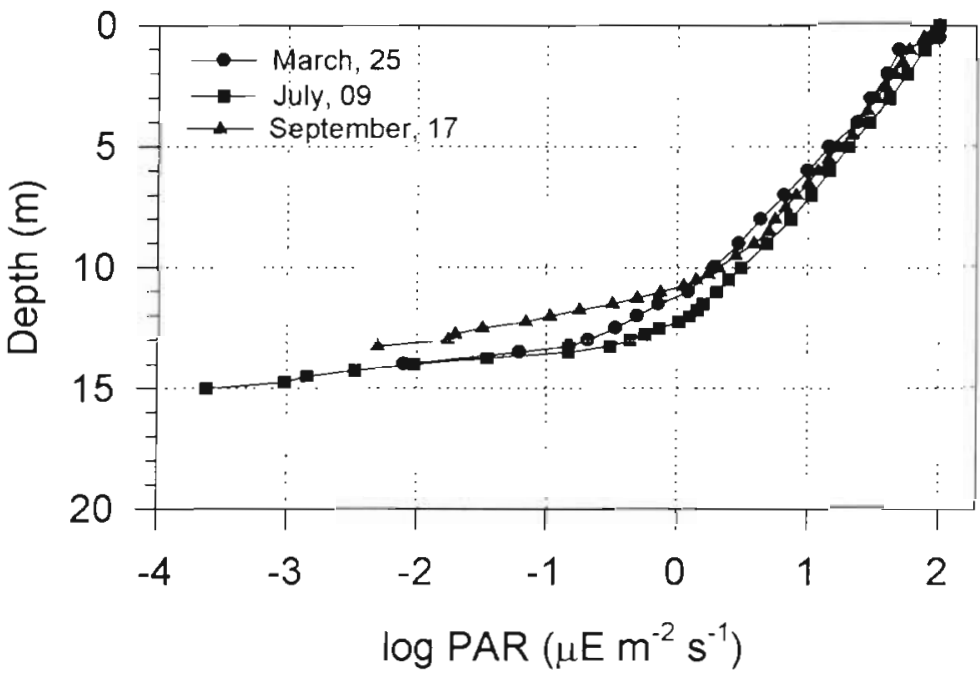

\begin{tabular}{lcc}
$\begin{array}{l}\text { Sampling } \\
\text { date }\end{array}$ & $\begin{array}{c}\text { Depth interval } \\
(\mathbf{m})\end{array}$ & $\begin{array}{c}\boldsymbol{\eta} \\
\left(\mathbf{m}^{-5}\right)\end{array}$ \\
\cline { 1 - 2 } March & 0.10 & 0.18 \\
& $11-13.25$ & 0.38 \\
& $13.5-14.5$ & 1.71 \\
& & \\
July & $0-11.75$ & 016 \\
& $12-13.25$ & 0.48 \\
& $13.5-15$ & 1.74 \\
& & \\
September & $0-9.5$ & 0.16 \\
& $10-1075$ & 0.35 \\
& $11-13.25$ & 0.97 \\
\hline
\end{tabular}

Fig. 1. Light penetration in Lake 'El Tobar' on the 3 sampling dates. Extinction coefficients calculated for the different layers are indicated 
Phototrophic sulphur bacteria were found forming a sharp plate, which overlaid the halocline. This narrow layer contained up to 5 distinct dominant species, which were spatially arranged in a vertical span of about $1.5 \mathrm{~m}$ (Fig. 2). These species were Chlorobium phaeobacteroides and Chlorobium vibrioforme plus 3 genera belonging to the purple sulphur bacterial group: (1) low counts of Thiospirillum, which was identified by direct microscopic observations of field samples; (2) Chromatium minus isolated in pure culture and identified according to morphometry and pigment composition (Staley et al. 1989); and (3) a third isolate of purple sulphur bacteria that was obtained in pure culture. According to morphometry and pigment composition we tentatively identified the latter bacterium as the moderate halophile Lamprobacter modestohalophilus. This assignment was later corroborated by molecular analysis. The $16 \mathrm{~S}$ rRNA sequence of this organism clustered with the $\gamma$-proteobacteria within the halophile purple sulphur bacteria. The EMBL database accession number assigned to this sequence is AJ011498.

During the spring phototrophic bacteria were poorly represented, reaching Bchl concentrations between 0.4 and $1.5 \mathrm{\mu g} \mathrm{l}^{-1}$. The sulphur phototrophic bacterial assemblages moved upwards dur-

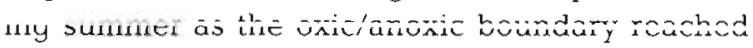
upper positions. These dynamics caused an increase in light intensity reaching the bacterial plate. In addition, the span of the transition zone also increased, and some populations such as Chromatium minus and Chlorobium phaeobacteroides were found at shallower positions (Table 1), which better suit their physiological requirements.

One feature was especially noticeable about the vertical structure of the studied phototrophic bacterial assemblage: the Lamprobacter modestohalophilus population was always found below Chlorobium phaeobacteroides. This vertical distribution, with a green sulphur bacterial population overlying a Chromatiaceae one, has not been reported to date. Brown-colored green sulphur bacteria are well adapted to low light intensities and therefore are frequently found in the deepest layers of the communities
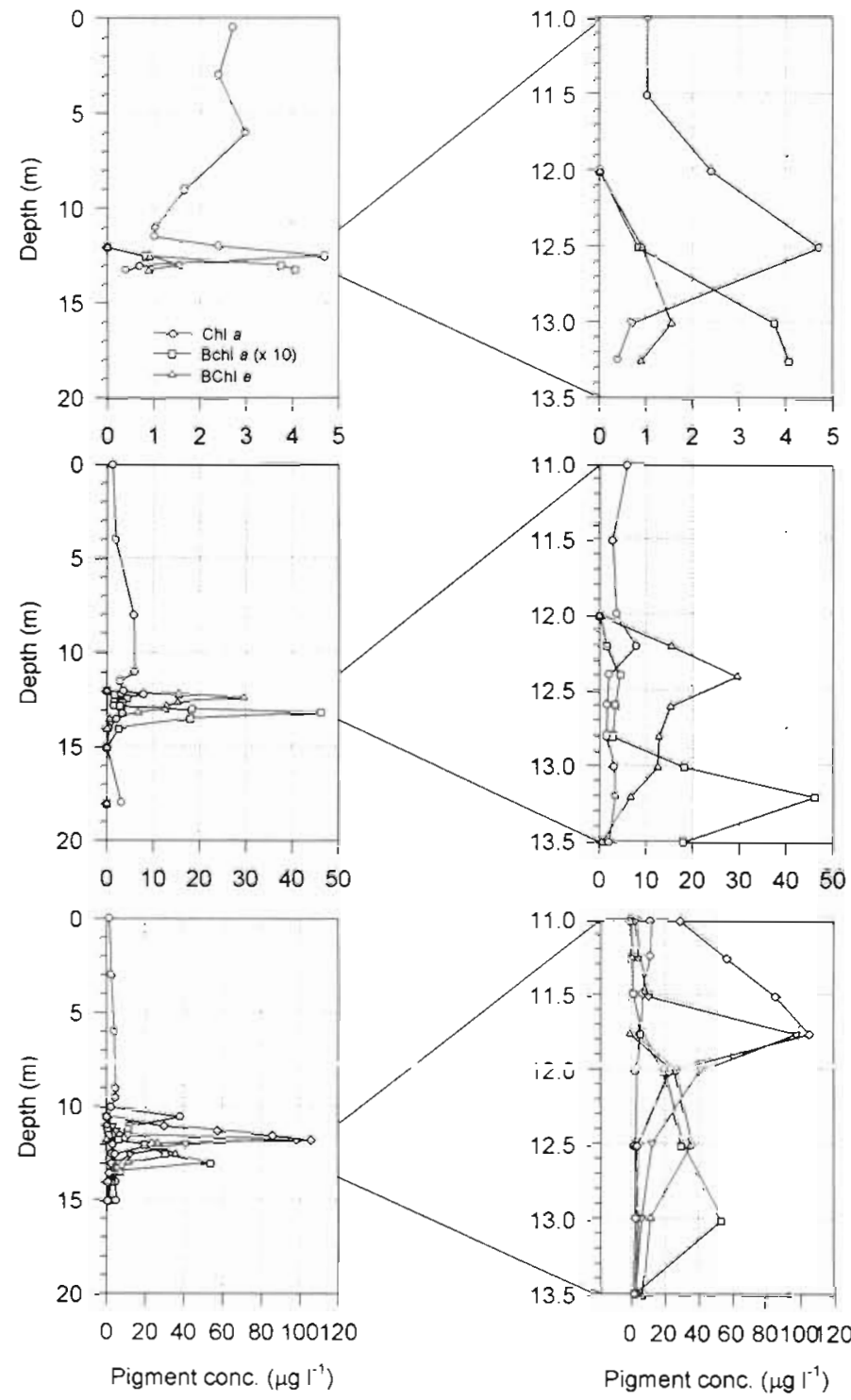

Fig. 2. Vertical distribution of photosynthetic pigments. Detailed distributions at gradient layers (11 to $13.5 \mathrm{~m}$ ) are shown in the right-hand panels

(Montesinos et al. 1983, Repeta et al. 1989, Ormerod et al. 1993). This vertical structure was constant throughout the period studied. Although it is rather unusual, this distribution can be explained by reference to the

Table 1. Mean conductivity values and positions (depth) of maximum cell densities

\begin{tabular}{|lcccccc|}
\hline & \multicolumn{2}{c}{ Mar 25 } & \multicolumn{2}{c|}{ Jul 9 } & \multicolumn{2}{c|}{ Sep 17 } \\
& $\begin{array}{c}\text { Cond. } \\
\left(\mathrm{mS} \mathrm{cm}^{-1}\right)\end{array}$ & $\begin{array}{c}\text { Depth } \\
(\mathrm{m})\end{array}$ & $\begin{array}{c}\text { Cond. } \\
\left(\mathrm{mS} \mathrm{cm}^{-1}\right)\end{array}$ & $\begin{array}{c}\text { Depth } \\
(\mathrm{m})\end{array}$ & $\begin{array}{c}\text { Cond. } \\
\left(\mathrm{mS} \mathrm{cm}^{-1}\right)\end{array}$ \\
\hline Chlorobium phaeobacteroides & $11.25 \pm 3.2$ & 13.0 & $9.83 \pm 3.92$ & 12.5 & $1.71 \pm 0.26$ & 11.0 \\
Chromatium minus & $11.25 \pm 3.2$ & 13.0 & $18.95 \pm 4.0$ & 12.5 & $1.81 \pm 0.25$ & 11.5 \\
Lamprobacter modestohalophilus & $25.22 \pm 10.7$ & 13.0 & $33.2 \pm 11.16$ & 13.0 & $22.9 \pm 4.07$ & 13.0 \\
Thiospirillum sp. & $25.22 \pm 10.7$ & 13.0 & $47.0 \pm 19.0$ & 13.0 & - & - \\
\hline
\end{tabular}


optimal salinity $(2 \%)$ at which the deepest Chromatiaceae develop. C. phaeobacteroides, in turn, is a freshwater species and it is therefore more likely to be found at low conductivity positions. This species, together with Synechococcus sp. and Chromatium minus were found in September at conductivity values close to those of freshwater ecosystems, whereas Thiospirillum sp. and L. modestohalophilus were constantly found at $13 \mathrm{~m}$, regardless of the season. C. phaeobacteroides and $C$. minus moved upwards from a depth of $13 \mathrm{~m}$ in March to $11 \mathrm{~m}$ in September. In the latter position salinity was similar $\left(1.7 \mathrm{mS} \mathrm{cm}^{-1}\right)$ to values found in other environments where these 2 species are commonly found (Garcia-Gil \& Abella 1992, Borrego et al 1993, Garcia-Gil et al. 1993, Bañeras \& Garcia-Gil 1996). Thus, it can be concluded that the phototrophic microbial community of Lake 'El Tobar' is vertically arranged according to the salinity gradient.

The presence of picoplanktonic deep maxima has been described in several meromictic lakes, and can be explained in terms of adaptation to nutrient competition, grazing, sulphide, oxygen and light (Craig 1987). Synechococcus sp. have displayed an optimal photon flux density of about $1 \%$ of surface, which is found in Lake 'El Tobar' at the chemocline level during summer. Phycoerythrin provides Synechococcus sp. cells with a selective advantage in terms of light competition under the green-enriched light conditions at this depth. In addition, phosphate concentrations at the chemocline are higher than those of epilimnetic waters, which are essential for optimal growth of Synechococcus sp., whose affinity for phosphate has been shown to be very low (Craig 1987).

Light reaching the upper part of the photosynthetic bacterial community was practically constant throughout the seasons. All these stratified populations were able to harvest photons under the prevailing light conditions. The light absorption by phycoerythrin-containing cyanobacteria was not strong enough to completely eliminate photons at the central spectral range, thus allowing their absorption by the Chlorobiaceaedominated freshwater community. The Soret band of Bchl e harvests photons in the 470 to $530 \mathrm{~nm}$ range, which is complementary to the cyanobacteria (Vila et al. 1996, Cox et al. 1998). These wavelengths are useless for the green-pigmented Chlorobiaceae (Montesinos et al. 1983, Pfennig 1989, Vila \& Abella 1994).

Finally, a Chromatiaceae-dominated saline assemblage was still able to develop with the remaining light. Although this group of phototrophic bacteria is known to have higher light requirements, the wide absorption range of their carotenoids enables them to collect photons from the whole spectral range (500 to $600 \mathrm{~nm}$ ) reaching the saline layer. The combination of an upper layer of brown Chlorobiaceae with a deeper one of Chromatiaceae appears to be the optimal situation for the coexistence of both microbial populations without strong negative up-to-down effects. Moreover, these populations can survive below phycoerythrincontaining cyanobacteria. This particular arrangement of the predominant populations of phototrophic sulphur bacteria is therefore more stable than the inverted combination, which is usually found in freshwater communities in which the wide spectral range of intense light absorption by Chromatiaceae populations greatly impairs the growth of the brown-colored Chlorobiaceae.

In addition to light intensity and quality, salinity was also a determining factor for the vertical segregation of the populations. A freshwater population was found in the upper positions, whereas unabsorbed light intensity was still high enough to power the development of a saline population placed immediately below. In summary, in Lake 'El Tobar' 2 selective tactors appear to determine the vertical structure of the photosynthetic bacterial community. Firstly, the salinity, which may segregate 2 distinct purple-plus-green assemblages and, secondly, light (both, intensity and quality), which may determine the relative position of green and purple bacteria (Fig. 3). In this double structure, only saline Chlorobiaceae were hard to find because in saline environments green bacteria are usually vibrio shaped (Imhoff 1995), which makes them difficult to distinguish from other heterotrophic bacteria under the microscope. However, Bchl $d$ clearly indicates the presence of Chlorobium vibrioforme. Nevertheless, 2 maxima were observable in some profiles, which strongly suggests that 2 complete purple-plus-green bacterial structures were sequentially present in Lake 'El Tobar'.

Another interesting microbiological feature of Lake 'El Tobar' is the presence of a high salinity picnocline that acts as 'fluid-sediment'. The density of the hyper-

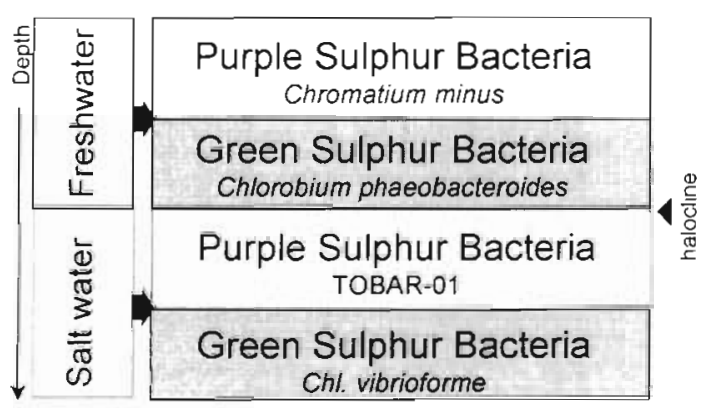

Fig. 3. Schematic representation of the double distribution of phototrophic sulphur bacteria found in Lake 'El Tobar' The usual vertical structure formed by purple (above) and green (below) sulphur bacteria is sequentially repeated in freshwater and saline environments within the same lake 
saline waters lying at the bottom causes the sedimentation rate to drop drastically. This forces the downward-moving organic matter to accumulate in a thin layer. A dense plate of heterotrophic bacteria occurs due to both decomposition and sulfide production. Vibrio-shaped bacteria were abundant in samples starting at $13 \mathrm{~m}$. Below this layer no signs of bacterial activity were observed due to the extremely high salinity level. However, it is necessary to further study the heterotrophic populations and their role in the anaerobic nutrient cycle

Acknowledgements. This work was supported by the $R+D$ project of the CICYT, CLI96-1103-CO2-01 and AMB 95-0323 to L.J.G.-G. Thanks are due to M. D. Sendra and V. Oliveras for their assistance in sampling and analytical procedures and to J. Figueras for helping with molecular biology work. Finally we are also indebted to Prof. Dr M. R. Miracle for her valuable help with field work and for discussion.

\section{LITERATURE CITED}

Bañeras L, Garcia-Gil LJ (1996) Role of photosynthetic microbial populations in the phosphorus exchange through the oxic anoxic boundary in a meromictic eutrophic lake. Arch Hydrobiol Spec Issues Adv Limnol 48:171-181

Borrego CM, Garcia-Gil LJ (1994) Separation of bacteriochlorophyll homologues from green photosynthetic sul-

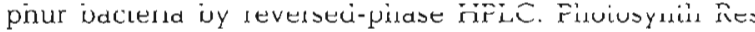
41:157-163

Borrego CM, Garcia-Gil LJ, Bañeras L, Brunet RC (1993) Changes in the composition of phototrophic sulphur bacterial communities in three basins of Lake Banyoles (Spain). Verh Int Ver Limnol 25:720-72.5

Borrego CM, Arellano JB, Abella CA, Gillbro T, Garcia-Gil LJ (1999) The molar extinction coefficient of bacteriachlorophyll $e$ and the pigment stoichiometry in Chlorobium phaeobacteroides. Photosynth Res 60:257-264

Cox R, Miller M, Aschenbrücker J, Ma YZ, Gillbro T (1998) The role of bacteriochlorophyll e and carotenoids in light harvesting in brown-colored green sulphur bacteria. In: Garab G (ed) Photosynthesis: mechanisms and effects Kluwer Academic Publishers, Dordrecht, p 149-152

Craig SR (1987) The distribution and contribution of picoplankton to deep photosynthetic layers in some meromictic lakes. Acta Acad Aboensis 47:55-81

Garcia-Gil LJ, Abella CA (1992) Population dynamics of phototrophic bacteria in three different basins of Lake Banyoles (Spain). Dev Hydrobiol Hydrobiologia 243/244:87-89

Garcia-Gil LJ, Borrego CM, Bañeras L, Abella CA (1993) Dynamics of phototrophic microbial populations in the chemocline of a meromictic basin of Lake Banyoles. Int Rev Ges Hydrobiol 78:283-294

\author{
Editorial responsibility: Tom Fenchel, \\ Helsingør, Denmark
}

Guerrero R, Montesinos E, Pedrós-Alió C. Esteve I, Mas J, van Gemerden H, Hofman PAG, Bakker JF (1985) Phototrophic sulphur bacteria in two Spanish lakes. Vertical distribution and limiting factors. Limnol Oceanogr 30:919-931

Imhoff JF (1995) Taxonomy and physiology of purple bacteria and green sulphur bacteria. In: Blanckenship RE, Madigan MT, Bauer CE (eds) Anoxygenic phototrophic bacteria. Kluwer Academic Publishers, Dordrecht, p 1-15

Jones JG (1979) Direct counts on membrane filters In: Freshwater Biological Association (eds) A guide to methods for estimating microbial numbers and biomass in freshwaters, Vol 39. Titus Wilson \& Son Ltd, Ambleside, p 19-39

Jørgensen BB, Kuenen JG, Cohen Y (1979) Microbial transformation of sulphur compounds in a stratified lake (Solar Lake, Sinai). Limnol Oceanogr 24:799-822

Miracle MR, Armengol-Diaz J, Dasí MJ (1993) Extreme meromixis determines strong differential planktonic vertical distributions. Verh Int Ver Limnol 25:705-710

Montesinos E, Guerrero R, Abella CA, Esteve I (1983) Ecology and physiology of the competition for light between Chlorobium limicola and Chlorobium phaeobacteroides in natural habitats. Appl Environ Microbiol 46(5): 1007-1016

Oelze J (1985) Analysis of bacteriochlorophylls. Meth Microbiol 18:257-284

Ormerod JG, Aukrust TW, Johnsen IJ (1993) Frugal Chlorobium: the ultimate phototroph. In: Guerrero R, PedrósAlió C (eds) Trends in microbial ecology. Spanish Society for Microbiology, Barcelona, p 59-62

Pfennig N (1989) Ecology of phototrophic purple and green sulphur bacteria. In: Schlegel HG, Bowien B (eds) Autotrophic bacteria. Science Tech Publ, Springer-Verlag, Berlin, p $97-116$

Repeta DJ, Simpson DJ, Jorgensen BB, Jannasch HN (1989)

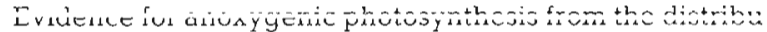
tion of bacteriochlorophyll in the Black Sea. Nature 342: $68-72$

Staley JT, Bryant MP, Pfennig N, Holt JG (eds) (1989) Bergey's manual of systematic bacteriology, Vol 3. Williams \& Wilkins, Baltimore

Takahashi M, Ichimura S (1968) Vertical distribution and organic matter production of phototrophic sulphur bacteria in Japanese lakes. Limnol Oceanogr 13:644-653

van Gemerden H, Mas J (1995) Ecology of phototrophic sulphur bacteria. In: Blankenship RE, Madigan MT, Bauer CE (eds) Anoxygenic photosynthetic bacteria. Advances in Photosynthesis, Vol II. Kluwer Academic Publishers, Dordrecht, p 49-85

Vicente E, Camacho A, Rodrigo MA (1993) Morphometry and physico-chemistry of the crenogenic meromictic Lake 'El Tobar' (Spain). Ver Int Ver Limnol 25:698-704

Vila X, Abella CA (1994) Effects of light quality on the physiology and the ecology of planktonic green sulphur bacteria in lakes. Photosynth Res 41:53-65

Vila X, Dokulil M, Garcia-Gil LJ, Abella CA, Borrego CM, Bañeras L (1996) Composition and distribution of phototrophic bacterioplankton in the deep communities of several central European lakes: the role of light quality. Arch Hydrobiol Spec Issues Adv Limnol 48:183-196

Submitted: November 11, 1998; Accepted: November 26, 1999 Proofs received from author(s): December 24, 1999 